\title{
A NEW GUINEA PIG (RODENTIA, CAVIOMORPHA) FROM NORTHWESTERN ARGENTINA: IMPLICATIONS FOR THE ORIGIN OF THE GENUS CAVIA
}

\author{
ADRIANA M. CANDELA $* 1,1$ and RICARDO A. BONINI ${ }^{2}$ \\ ${ }^{1}$ CONICET-División Paleontología Vertebrados, Facultad de Ciencias Naturales y Museo, Paseo del Bosque s/n, B1900FWA, \\ La Plata, Argentina, acandela@fcnym.unlp.edu.ar; \\ ${ }^{2}$ INCUAPA CONICET, Universidad Nacional del Centro de la provincia de Buenos Aires, Av. del Valle 5737, B7400JWI Olavarría, \\ Argentina, rbonini@fcnym.unlp.edu.ar
}

\begin{abstract}
We describe a new caviomorph rodent, Cavia cabrerai, sp. nov. (Caviidae, Caviinae), from the upper levels of Andalhuala Formation (San Fernando Norte locality, Catamarca Province, northwestern Argentina), which represents the oldest fossil record of the genus. The new species differs from extant and extinct species of Cavia by a unique combination of characters: large size, proportionally anteroposteriorly elongated molars, slightly anteroposteriorly compressed prisms, relatively shallow primary lingual flexids, abundant cement in the lingual flexids, and anterolingual widening of the second crests of cheek teeth. A phylogenetic analysis indicates that Cavia cabrerai, sp. nov., is the sister taxon of extant Cavia species and displays dental characters more plesiomorphic than the latter. Some characters of $C$. cabrerai, sp. nov., namely, compression of prisms and depth of flexids, are morphologically intermediate between the related extinct Caviinae Palaeocavia and the extant species of Cavia. An ash bed dated at $4.72 \pm 0.08$ Ma that overlies the fossiliferous level of the new material supports the presence of Cavia close to the Miocene-Pliocene boundary. The origin of Cavia may have been triggered by the expansion of relatively open and arid environments that arose near the Miocene-Pliocene boundary.
\end{abstract}

http://zoobank.org/urn:lsid:zoobank.org:pub:3A6E6666-1FBE-4C6E-95CA-4B33927A414D

SUPPLEMENTAL DATA—Supplemental materials are available for this article for free at www.tandfonline.com/UJVP

Citation for this article: Candela, A. M., and R. A. Bonini. 2017. A new guinea pig (Rodentia, Caviomorpha) from northwestern Argentina: Implications for the origin of the genus Cavia. Journal of Vertebrate Paleontology. DOI: 10.1080/ 02724634.2017.1352591.

\section{INTRODUCTION}

The extant species of genus Cavia, usually known as guinea pigs but also called 'cuyes,' 'apereás,' 'cuises,' 'cavies,' or 'preás,' depending on geographical location, are caviomorph rodents that are relatively common in Neotropical mammalian communities. The wild species are essentially terrestrial and mediumsized caviids (subfamily Caviinae sensu Madozzo-Jaén and Pérez, 2016), distributed in much of South America, excluding the Amazon basin and the middle to high latitudes of Chile and Argentina (Ximénez, 1980; Eisenberg, 1989; Redford and Eisenberg, 1992; Eisenberg and Redford, 1999; Bonvicino et al., 2008; Ortiz and Jayat, 2012; Dunnum, 2015). The domesticated Cavia porcellus (probably originating from populations of C.t. tschudii; Dunnum and Salazar-Bravo, 2010; see also Spotorno et al., 2004) is a cosmopolitan species that occurs throughout South America (Dunnum and Salazar-Bravo, 2010; Dunnum, 2015). A recent molecular systematic analysis recognized six wild extant species: Cavia aperea, C. fulgida, C. intermedia, C. magna, C. tschudii, and C. patzelti (Dunnum and Salazar-Bravo, 2010; see also Cabrera, 1953; Ximénez, 1980; Cherem et al., 1999; Woods and Kilpatrick, 2005; Dunnum, 2015). These species occupy diverse South American biomes, occurring from mesic lowlands to the highlands of the Central Andean range (up to $4200 \mathrm{~m}$ above sea level [asl]) (e.g., Woods and Kilpatrick, 2005;

\footnotetext{
*Corresponding author.
}

Bonvicino et al., 2008; Dunnum and Salazar-Bravo, 2010; Ortiz and Jayat, 2012; Dunnum, 2015, and references therein).

Cavia species have euhypsodont cheek teeth with a characteristic laminar pattern, formed essentially by two prisms separated by a deep fold filled with cement (Kraglievich, 1930; Cabrera, 1953; Pascual and Ortega Hinojosa, 1966; Quintana, 1996, 1997). This dental morphology is more complex than that of any other non-Cavia Caviinae (e.g., Microcavia and Galea) or Dolichotinae (e.g., Dolichotis).

Three extinct species of Cavia have been described: C. galileoi Verzi and Quintana, 2005, from the late Pliocene of Buenos Aires Province, and C. vates Winge, 1887, and C. lamingae Lock and Montenegro, 1985, both from late Pleistocene-Holocene deposits of the Lagoa Santa caves, in the Brazilian state of Minas Gerais. Fossil records of Cavia are also known from the middle Pleistocene of Uruguay (Ubilla and Alberdi, 1990) and the Holocene of diverse archeological sites throughout South America (Dunnum and Salazar-Bravo, 2010, and references therein). Fossil specimens of C. porcellus have been reported from the Quaternary of Minas Gerais (Winge, 1887) and of Cavia aperea and C. magna from the Holocene of Rio Grande do Sul, Brazil (Hadler et al., 2008). In contrast to these relatively modern fossil records, divergence estimates from molecular data indicate that the genus (crown clade) originated in the early Pliocene $(4.1 \pm 1.6 \mathrm{Ma}$; Opazo, 2005) or earlier, well into the late Miocene (Dunnum and Salazar-Bravo, 2010; see also Madozzo-Jaén and Pérez, 2016).

In this contribution, we describe new specimens of Cavia from early Pliocene sediments corresponding to the Formation, 
cropping out in San Fernando Norte locality (Belén Department, Catamarca Province, northwestern Argentina; Fig. 1A, B), which represent the oldest fossil record of the genus in South America. We discuss their taxonomic assignation to a new species and analyze their phylogenetic relationships. Based on a ${ }^{40} \mathrm{Ar} /{ }^{39} \mathrm{Ar}$ age of $4.72 \pm 0.08 \mathrm{Ma}$ for the upper levels of Andalhuala Formation (Bonini et al., in press; Fig. 1C), which constrains the age of the fossiliferous level, we assess the early origin of the genus and the paleoenvironmental implications of the new finding.

Institutional Abbreviations-AMNH, American Museum of Natural History, New York, New York, U.S.A.; MACN, Museo Argentino de Ciencias Naturales 'Bernardino Rivadavia,' Buenos Aires, Argentina; MCH-P, Museo Arqueológico Provincial 'Condor Huasi,' Sección Paleontología, Belén, Catamarca, Argentina; MLP, Museo de La Plata, La Plata, Buenos Aires, Argentina; MNHN, Museo Nacional de Historia Natural de
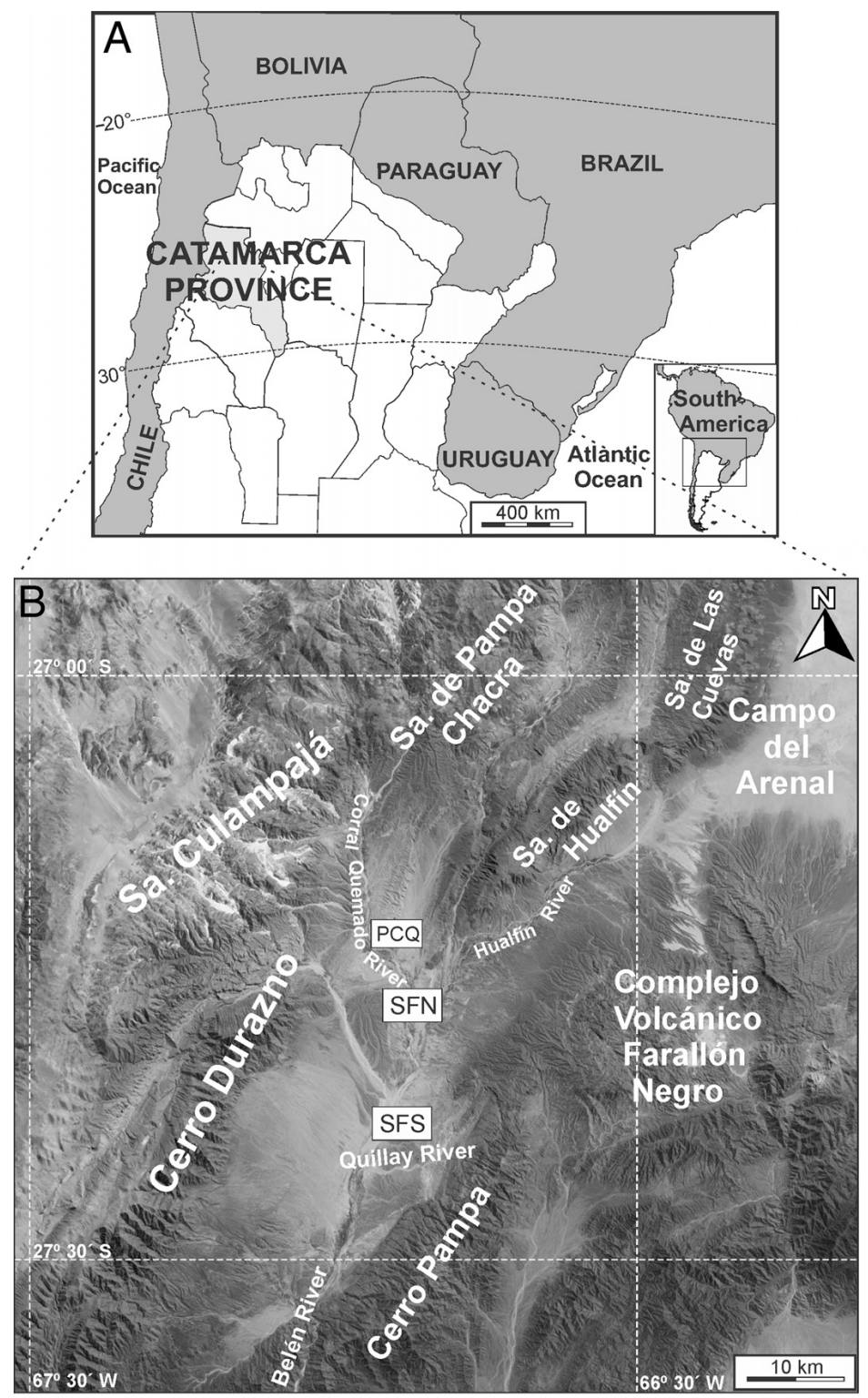

Montevideo, Montevideo, Uruguay; MPS-Z, Museo de Ciencias Naturales 'P. Antonio Scasso San Nicolás', Buenos Aires, Argentina; MZUSP, Museum of Zoology of the University of São Paulo, São Paulo, Brazil; UFSC, Universidade Ferderal do Rio Grande do Sul, Brazil; ZMUC, Zoological Museum, Natural History Museum of Denmark, University of Copenhagen, Copenhagen, Denmark.

\section{MATERIALS AND METHODS}

\section{Comparative Specimens}

The new material here described is housed in the MCH-P. It was compared with specimens of extant species of Cavia housed in the MACN, MLP, and MPS-Z (Supplementary Data 1). Additional information on extant species of Cavia was obtained from the literature (Cabrera, 1953; Ximénez, 1980; Quintana, 1998; 
Cherem et al., 1999; Bonvicino et al., 2008; Cherem and Ferigolo, 2012; Dunnum, 2015; Brito and Férnandez de Córdova, 2016). Data on the extinct Cavia galileoi (late Pliocene, Argentina), C. vates, and C. lamingae (Pleistocene-Holocene of Brazil) were taken from Winge (1887), Locks and Montenegro (1985), and Verzi and Quintana (2005). The type of $C$. vates was studied through photos provided by the curator of the Lund Collection of ZMUC. The new specimens were also compared with materials corresponding to the extant caviines (sensu Madozzo-Jaén and Pérez, 2016) Microcavia, Cavia, and Galea, and the extinct Dolicavia minuscula (Ameghino, 1908), Palaeocavia impar (Ameghino, 1888) and Palaeocavia chapalmalense (Ameghino, 1908). The comparative study of caviines was also based on information published in several contributions (Ameghino, 1888, 1889, 1908; Kraglievich, 1930, 1940; Cabrera, 1953; Pascual and Ortega Hinojosa, 1966; Quintana, 1996, 1997, 1998; Verzi and Quintana, 2005; Madozzo-Jaén and Pérez, 2016). Dental nomenclature follows Quintana (1996), Madozzo-Jaén and Pérez (2016), and Verzi and Quintana (2005). Measurements were taken in $\mathrm{mm}$.

Other Abbreviations-AWPP, anterolingual widening in anterior crest of posterior prism of teeth; HPI, primary internal flexid ( = lingual flexid).

\section{Body Mass}

Body mass (BM) of C. cabrerai, sp. nov. was estimated using the equations obtained by Legendre (1986), based on the occlusal area of $\mathrm{m} 1$. We compared the body mass estimated for $C$. $c a b$ rerai, sp. nov., with the values obtained by applying this equation to molars of two specimens of $C$. aperea and $C$. porcellus (Table 1) with known body masses (Table 2).

\section{Phylogenetic Analysis}

In order to assess the phylogenetic relationships of the new species within Caviidae, a cladistic analysis was performed using a modified version of the combined data set of Madozzo-Jaén and Pérez (2016:supplementary data 2), which originally included 54 taxa (53 cavioid taxa and one octodontoid for rooting the most parsimonious trees), 117 morphological characters, and DNA sequences from two mitochondrial (12S and $C y t b)$ and two nuclear ( $G h r$ and $T t h)$ genes from GenBank for 11 extant taxa (Madozzo-Jaén and Pérez, 2016:supplementary data 1). We included the new species $C$. cabrerai sp. nov. in the data set of Madozzo and Pérez (2016) (Supplementary Data 2), which was analyzed with methodology identical to the one applied by these authors. Thus, equally weighted parsimony analysis was conducted using TNT 1.1 (Goloboff et al., 2008), treating gaps as missing data for the DNA sequences; a heuristic search of 1000 Wagner tree replicates followed by tree bisection reconnection (TBR) branch swapping was conducted to find the most parsimonious trees (MPTs), collapsing zero-length branches under the strictest criterion. Unstable taxa, identified in the set of MPTs (Madozzo-Jaén and Pérez, 2016), were pruned in order to derive an informative reduced consensus. In a first analysis, we considered as ordered the same 22 multistate characters as in the original data set (Madozzo-Jaén and Pérez, 2014:supplementary data 1 ). In a second analysis, we also considered character 96, originally defined as 'Depth of HPI in $\mathrm{m} 1-\mathrm{m} 2$ ' with four character states: "shallow (0); up to $25 \%$ (1); up to $50 \%$ (2); reaching the labial end (3); dividing the prism (4)" (Madozzo-Jaén and Pérez, 2016:supplementary data 1), as ordered, on the basis of the increasing degrees of similarity between the character states identified for this character. The new species was scored as 2 for this character, whereas the extant Cavia species were scored as 3 . In the second analysis, the character states for character 86 (i.e., 'Shape of the anterior lobe of m1-m2'; Madozzo-Jaén and Pérez, 2016:supplementary data 1) were also modified. Based on new information provided by the study of the new species (see below), we identified five states for character 86: triangular (0); heart-shaped (1); lanceolate (leaf-shaped) (2); laminar, being less anteroposteriorly compressed than the anteroposterior diameter of the hypoflexid (3); and strongly laminar, being equally or more anteroposteriorly compressed than the hypoflexid (4). Cavia cabrerai, sp. nov., was scored as 3 for this character (as in the first analysis), whereas the extant species were scored as 4 (Supplementary Data 2).

\section{GEOLOGICAL SETTING AND AGE}

The San Fernando locality is situated in Belén Department, approximately $50 \mathrm{~km}$ north-northeast of Belén City, in northwestern Catamarca Province (Fig. 1A, B). The locality is divided into two villages: San Fernando Sur or Capillanía $\left(27^{\circ} 20^{\prime} \mathrm{S}\right.$, $\left.67^{\circ} 53^{\prime} \mathrm{W}\right)$ and San Fernando Norte or La Villa $\left(27^{\circ} 16^{\prime} \mathrm{S}\right.$, $\left.66^{\circ} 54^{\prime} \mathrm{W}\right)$. The Neogene lithostratigraphic units recognized in San Fernando Norte locality, from which the new specimens

TABLE 1. Mandibular and lower cheek teeth measurements (in mm).

\begin{tabular}{|c|c|c|c|c|c|c|}
\hline Dimension & $\begin{array}{c}\text { Cavia cabrerai, sp. nov. } \\
\text { MCH-P } 170\end{array}$ & $\begin{array}{l}\text { C. cabrerai, sp. nov. } \\
\text { MCH-P } 196\end{array}$ & $\begin{array}{c}\text { C. galileoi } \\
\text { MACN } 19721\end{array}$ & $\begin{array}{l}\text { C. aperea } \\
\text { MPS-Z } 211\end{array}$ & $\begin{array}{l}\text { C. porcellus } \\
\text { MPS-Z } 212\end{array}$ & $\begin{array}{c}\text { C. magna } \\
\text { AMNH 235998* }\end{array}$ \\
\hline APL p4 & 4.22 & & 3.38 & 3.20 & 4.04 & - \\
\hline AW p4 & 2.75 & & & 2.36 & 2.62 & - \\
\hline PW p4 & 3.40 & & 3.05 & 2.88 & 3.14 & - \\
\hline APL m1 & 4.44 & 4.17 & 4.16 & 3.22 & 3.70 & - \\
\hline AW m1 & 3.81 & 3.46 & 3.27 & 3.22 & 3.46 & - \\
\hline PW m1 & - & & - & 3.44 & 3.62 & - \\
\hline APL m2 & 4.36 & & & 3.29 & 3.64 & - \\
\hline $\mathrm{AW} \mathrm{m} 2$ & - & & & 3.24 & 3.53 & - \\
\hline PW m2 & 4.41 & & & - & 3.56 & - \\
\hline APL m3 & ca. 4.52 & & & 3.25 & 4.01 & - \\
\hline $\mathrm{AW}$ m3 & - & & & 3.08 & 3.63 & - \\
\hline PW m3 & - & & & 3.21 & 3.74 & - \\
\hline P4-m3 length & ca.18.10 & & & 13.29 & 16.60 & 16 \\
\hline m1-m3 length & ca. 13.89 & & & 9.76 & 11.40 & - \\
\hline Lower diastema length & ca. 14.70 & & & 12.27 & 12.63 & - \\
\hline Mandibular height ${ }^{* *}$ & 7 & & & 5.94 & 6.64 & - \\
\hline
\end{tabular}

Abbreviations: APL, anteroposterior length; AW, anterior width; PW, posterior width.

*From Ximénez (1980).

**Taken at diastema level in front $\mathrm{p} 4$. 
TABLE 2. Body mass (in grams) of specimens of different species of Cavia.

\begin{tabular}{|c|c|c|c|c|c|c|c|c|}
\hline Body mass & $\begin{array}{l}\text { Cavia cabrerai, } \\
\text { sp. nov. }\end{array}$ & $\begin{array}{c}\text { C. aperea } \\
\text { MACN } 23387\end{array}$ & $\begin{array}{l}\text { C. aperea } \\
\text { MPS-Z } 211\end{array}$ & $\begin{array}{l}\text { C. porcellus } \\
\text { MPS-Z } 212\end{array}$ & $\begin{array}{l}\text { C. magna Holotype } \\
\text { MZUSP } 11.843\end{array}$ & $\begin{array}{l}\text { C. magna } \\
\text { AMNH } \\
235998^{*}\end{array}$ & $\begin{array}{l}\text { C. intermedia } \\
\text { MNHN } 3272^{* *}\end{array}$ & $\begin{array}{c}\text { C. intermedia } \\
\text { Holotype UFSC } \\
585^{* *}\end{array}$ \\
\hline Known BM & - & - & 590 & 800 & 760 & 790 & 550 & 680 \\
\hline
\end{tabular}

Abbreviation: BM, body mass.

*From Ximénez (1980).

**From Cherem et al. (1999).

here described were collected, comprise, from base to top: the Las Arcas, Chiquimil, Andalhuala, and Corral Quemado formations, and the 'Punaschotter' unit, the Andalhuala Formation being the most extensive unit in the area (Fig. 1C) (Muruaga, 2001a, 2001b; Bossi and Muruaga, 2009; Bonini and Georgieff, 2013). The upper levels of Andalhuala Formation are the fossiliferous beds that have yielded the new materials studied here. These specimens were collected from facies of brown sandstone with fine to coarse grain size, with trough lenticular cross-stratified sandstones interbedded with facies of tabular reddish siltstone with massive stratification, which can be identified as channel deposits and/or sandbars (Bridge et al., 2000; Bridge and Demico, 2008; Bonini et al., in press). These sedimentary levels lie approximately $18 \mathrm{~m}$ below a level that has yielded an age of $4.72 \pm 0.08 \mathrm{Ma}$ and $45 \mathrm{~m}$ above another level with an age of $4.79 \pm 0.15 \mathrm{Ma}$, according to $\mathrm{Ar}^{39} / \mathrm{Ar}^{40}$ dating (Bonini and Brandoni, 2015; Bonini et al., in press Fig. 1C). From these absolute ages, and assuming that deposition has remained constant and uninterrupted, the sedimentation rate was estimated at $0.78 \mathrm{~m} / \mathrm{ka}$ for these levels. On this basis, an age of approximately 4.74 $\mathrm{Ma}$ is herein proposed for the time of deposition of the fossiliferous level.

\section{SYSTEMATIC PALEONTOLOGY}

RODENTIA Bowdich, 1821

CAVIOMORPHA Wood and Patterson in Wood, 1955

CAVIIDAE Fischer von Waldheim, 1817

CAVIINAE Fischer von Waldheim, 1817

Genus CAVIA Pallas, 1766

Type species-Cavia cobaya Pallas, 1766 ( = Mus porcellus Linnaeus, 1758).

CAVIA CABRERAI, sp. nov.

(Figs. 2, 3)

Holotype-MCH-P 170, right broken mandible represented by two portions: the anterior mandibular portion with the diastema, symphysis, and $\mathrm{p} 4$, and the posterior one with the m1-m3 series.

Referred Specimen-MCH-P 196, an isolated lower right molar (probably an $\mathrm{m} 1$ because of size similar to that of the $\mathrm{m} 1$ of the holotype; Table 1).

Locality and Horizon-Upper levels of Andahuala Formation (ca. $4.74 \mathrm{Ma})$; San Fernando Norte $\left(27^{\circ} 16^{\prime} \mathrm{S}, 66^{\circ} 54^{\prime} \mathrm{W}\right)$, Belén Department, Catamarca Province, northwestern Argentina.

Diagnosis-Cavia cabrerai, sp. nov., is the largest species of the genus (Table 2), differing from extant species of Cavia by having cheek teeth with less anteroposteriorly compressed prisms (i.e., less laminar occlusal pattern), hypoflexid relatively less penetrating, lingual flexid (= primary internal flexid) shallower and narrower, and $\mathrm{m} 1-\mathrm{m} 3$ proportionally narrower. It differs from $C$. galileoi by having abundant cement in the lingual flexids, and from $C$. galileoi and $C$. vates by having $\mathrm{m} 1-\mathrm{m} 3$ with an anterolingual widening in the anterior crest of the posterior prisms, and a relatively larger $\mathrm{p} 4$. It differs from the remaining species by having the $\mathrm{p} 4$ with one anterior projection in the anterior lobe.

Etymology-In honor of Ángel Cabrera y Latorre for his exhaustive and pioneering paleontological research at the San Fernando and Puerta de Corral Quemado localities in Catamarca Province and his important contributions on Caviidae. Epithet is treated in second declension, masculine (genitive, singular: i).

\section{Comparative Description}

Based on the dental measurements (Table 1) and estimated body mass (Table 2), as well as information provided by bibliographic research, Cavia cabrerai, sp. nov., may be considered as the largest known species of the genus.

Mandible - The set of mandibular features is similar to that of other species Cavia. The anterior-most margin of the diastema, corresponding to the alveolar border of the incisor, is missing. Its anterior end projects above the level of the alveolar border of p4. The diastema is shorter than the p4-m3 length (Fig. 2; Table 1), and a well-developed posteroventral projection of the mandibular symphysis is visible in lateral view (exposed in lateral view; Madozzo-Jaén and Pérez, 2016; Fig. 2A). The mental foramen (visible in lateral view) is located above the dorsoventral midpoint of the lateral surface of the dentary and opens dorsolaterally. The anterior portion of the mandibular symphysis is higher than the level of the alveolar borders of the cheek teeth, and its posterior end is anterior to the 44 (Fig. 2B).

Dentition-Similar to the other species of Cavia, C. cabrerai, sp. nov., has euhypsodont cheek teeth formed by two prisms (lobes) connected by a short and narrow lingual isthmus, which represents the bottom of the hypoflexid (Fig. 2C). The lingual isthmus is formed by a double layer of enamel filled with dentine. This isthmus is posterolabially connected with the crest posterior to the hypoflexid ( = anterior crest of the posterior prism), which is more labiolingually extensive than that of Palaeocavia (Verzi and Quintana, 2005). In the new species, the hypoflexus extends across the tooth beyond the midpoint of the crown and is less penetrating than in extant species of Cavia and $C$. lamingae. The latter species presents a thinner lingual isthmus (Lock and Montenegro, 1985), as in extant species, in which this isthmus is formed by a single layer of enamel. In all cheek teeth, the hypoflexid is narrow and long and contains abundant cement, as in other species of the genus. Similarly to the extinct Cavia vates and C. galileoi, the cheek teeth of $C$. cabrerai, sp. nov., display a less laminar occlusal pattern, i.e., its anterior and posterior prisms are less anteroposteriorly compressed than those of the extant species and $C$. lamingae. The enamel is thicker on the labial border of the prisms and reduced on the lingual surfaces, as in other species of the genus (Madozzo-Jaén and Pérez, 2016). In all cheek teeth, the primary internal flexid (HPI) is narrower and shallower (extending to ca. $50 \%$ of 
FIGURE 2. Cavia cabrerai, sp. nov. A-C, MCH-P 170, holotype (right mandible with $\mathrm{m} 1-\mathrm{m} 3$ series, and anterior mandibular portion with diastema, symphysis, and p4); $\mathbf{A}, \mathbf{B}$, anterior mandible portion with $\mathrm{p} 4$ in $\mathbf{A}$, lateral and $\mathbf{B}$, lingual views; $\mathbf{C}$, cheek teeth in occlusal view; D, MCH-P 196, right $\mathrm{m} 1$ ? in occlusal view. Abbreviations: ap, anterior prism ( $=$ anterior lobe); app4, additional prolongation of $\mathrm{p} 4$; awpp, anterolingual widening of the anterior crest of posterior prism; c, cement; Hf, hypoflexid; hpi, primary internal flexid ( = lingual flexid); m1, lower first molar; m2, lower second molar; $\mathbf{m 3}$, lower third molar; p4, lower fourth premolar; pp, posterior prism ( $=$ posterior lobe $)$.
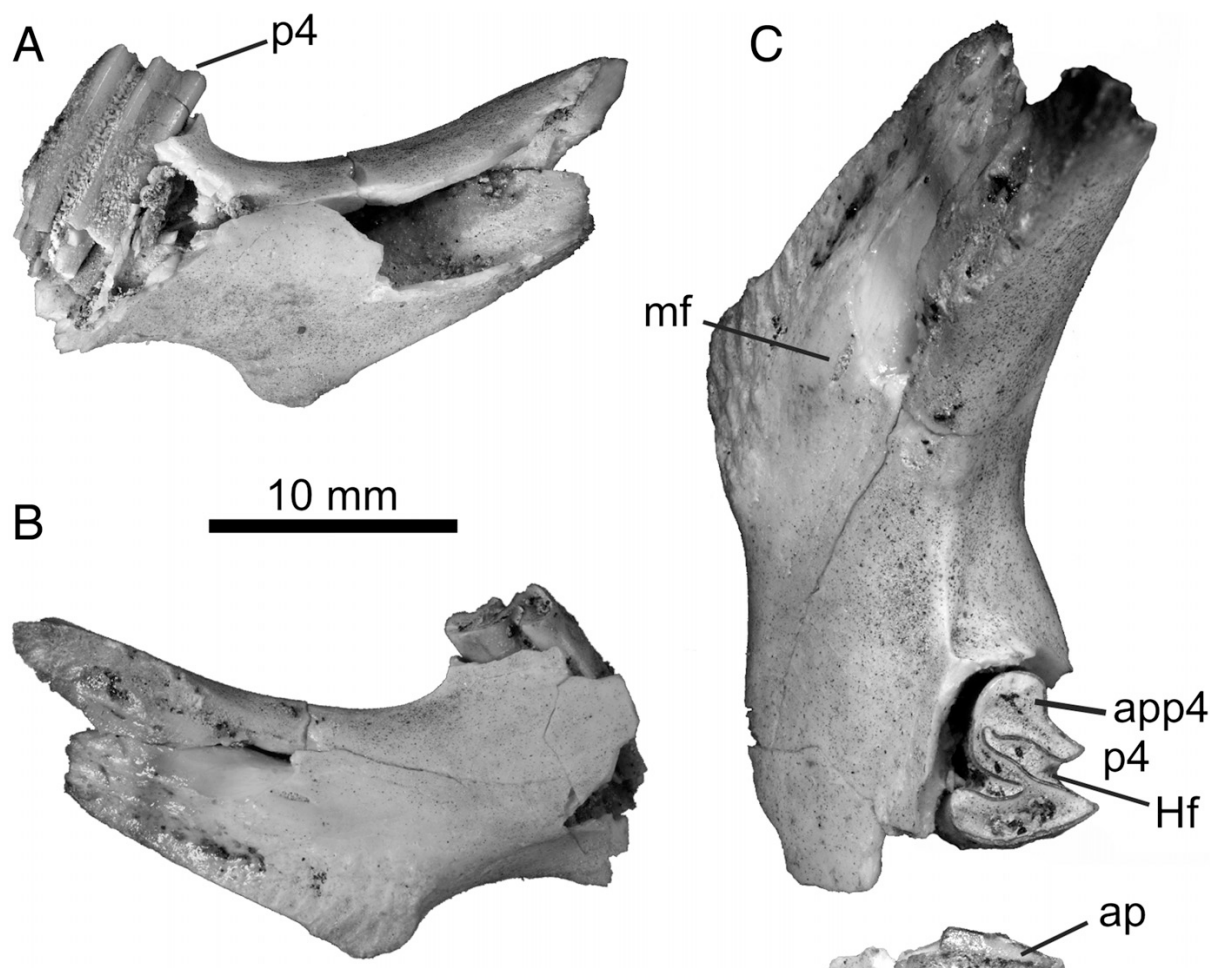

D
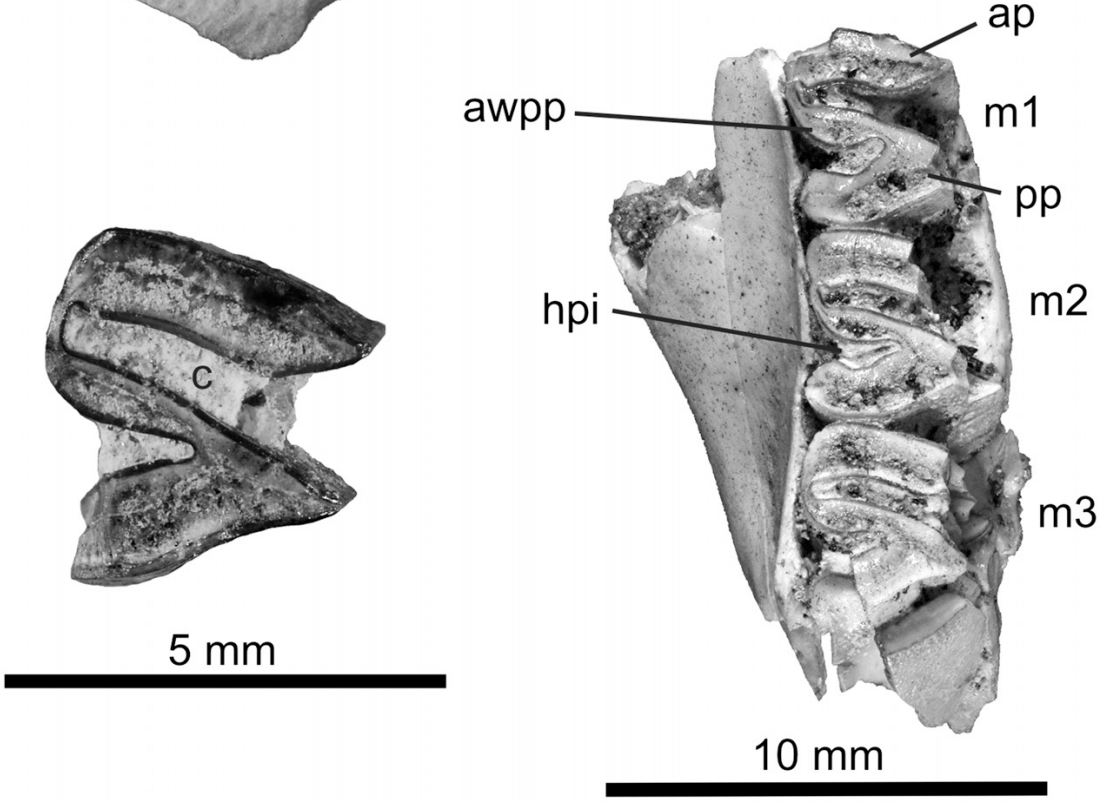

the total tooth width) than in extant species, resembling $C$. vates. In MCH-P 196 (Fig. 2C), HPI is less anterolingually oriented and somewhat deeper than the HPI of the holotype. Unlike C. galileoi (Verzi and Quintana, 2005), and as in living species, the HPI contains abundant cement (we were not able to corroborate the existence of cement in the HPI of cheek teeth of $C$. vates).

The $\mathrm{p} 4$ is longer than wide and somewhat shorter than the $\mathrm{m} 1$, being proportionally larger than that of $C$. galileoi (Verzi and Quintana, 2005). In C. cabrerai, sp. nov., the anterior prism of $\mathrm{p} 4$ is slightly elongated anteriorly, being similar in shape to that of some living specimens of Cavia, but more developed than the latter, and differing from the $\mathrm{p} 4$ of $C$. vates, $C$. galileoi (Verzi and Quintana, 2005:fig. 4), and Palaeocavia impar (Madozzo-Jaén and Pérez, 2016). In the later species and most of the specimens of extant species examined, the anterior prism of p4 is markedly obliquely oriented and not anteriorly projected. The anterior elongation ( $=$ additional elongation) of $\mathrm{p} 4$ of $C$. cabrerai, $\mathrm{sp}$. nov., is not clearly delimited by a labial flexid, unlike the condition in other caviines (Microcavia, Galea) in which this labial flexid is well developed. The degree of development of the anterior elongation of the $\mathrm{p} 4$ seems to be a variable feature within the genus Cavia (Verzi and Quintana, 2005:fig. 1F, H) and even within the same species (Cavia aperea), but in the latter this projection does not reach the degree of development of $C$. cabrerai, sp. nov. In C. cabrerai, sp. nov., the hypoflexid is narrow, long, and delimited by sinuous walls. The anterior crest of the posterior prism (posterior to the hypoflexid) has an anterolingual widening (AWPP), such as the one that characterizes the living species (Verzi and Quintana, 2005), distinguishing them from $C$. galileoi, C. vates, and Palaeocavia (Madozzo-Jaén and Pérez, 2016). 

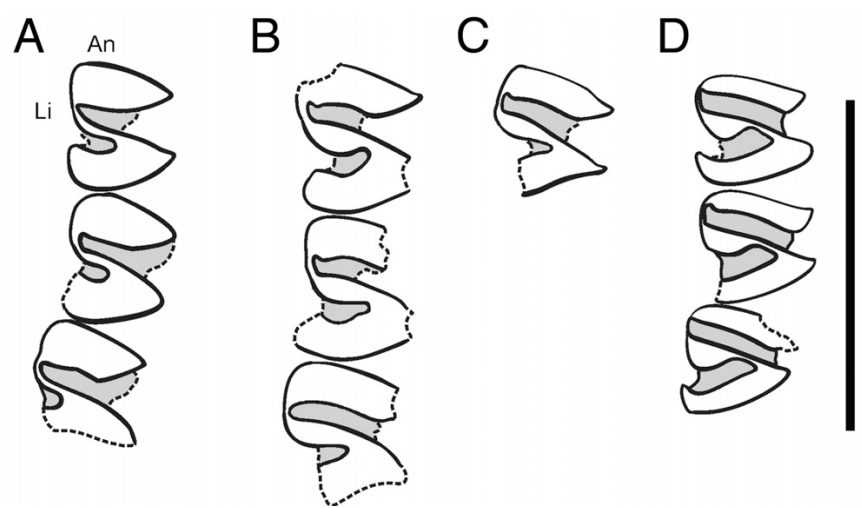

FIGURE 3. Schematic comparative drawings of $\mathrm{m} 1-\mathrm{m} 3$ of Palaeocavia and Cavia in occlusal view. A, Palaeocavia chapalmalense, MACN 15307, left m1-m3 reflected. B, Cavia cabrerai, sp. nov., MCH-P 170, holotype, right m1-m3. C, Cavia cabrerai, sp. nov., MCH-P 196, right m1? D, Cavia aperea, MPS-Z 209, left m1-m3 reflected. Black: enamel; gray: cement; white: dentine. Abbreviations: An, anterior; $\mathbf{L i}$, lingual. Scale bar equals $10 \mathrm{~mm}$.

The $\mathrm{m} 1-\mathrm{m} 3$ are somewhat longer than wide and proportionally narrower than those of living species (Table 1). The anterior prisms of $\mathrm{m} 1-\mathrm{m} 3$ are more anteroposteriorly extended than the anteroposterior diameter of the hypoflexid of these teeth (i.e., in $\mathrm{m} 1-\mathrm{m} 3$ of the holotype, the anteroposterior diameter of the anterior prism is about twice the anteroposterior diameter of the hypoflexid; Fig. 2C; in MCH-P 196, the hypoflexid is somewhat more open labially than that of the holotype; Fig. 2D). On the other hand, in extant species, the anterior prism of the m1$\mathrm{m} 3$ is subequal to the hypoflexid in anteroposterior diameter. Thus, in $C$. cabrerai, sp. nov., the anterior prisms are much less laminar in shape than those of extant species and resemble those of $C$. vates and $C$. galileoi. In turn, the anterior prisms of the $\mathrm{m} 1-\mathrm{m} 3$ are more laminar (i.e., more anteroposteriorly compressed) than the posterior prisms. The posterior borders of the anterior prisms of the $m 1-\mathrm{m} 3$ are slightly concave posteriorly (a feature more evident in the holotype than in MCH-P 196). As in extant species, the m1-m3 of the holotype have a well-defined AWPP (Verzi and Quintana, 2005), more so than that of MCH-P 196. This feature differs from the condition in the extinct $C$. galileoi (Verzi and Quintana, 2005) and C. vates, which lack AWPP and present a lingually narrow second crest in all cheek teeth. The AWPP of the molars in C. cabrerai, sp. nov., is more developed than that of the p4. Unlike in extant species and $C$. galileoi, the posterior crest of the posterior prism in all teeth is more anteroposteriorly extended than the HPI (i.e., the posterior crest is about twice the anteroposterior diameter of the HPI). Consequently, as noted

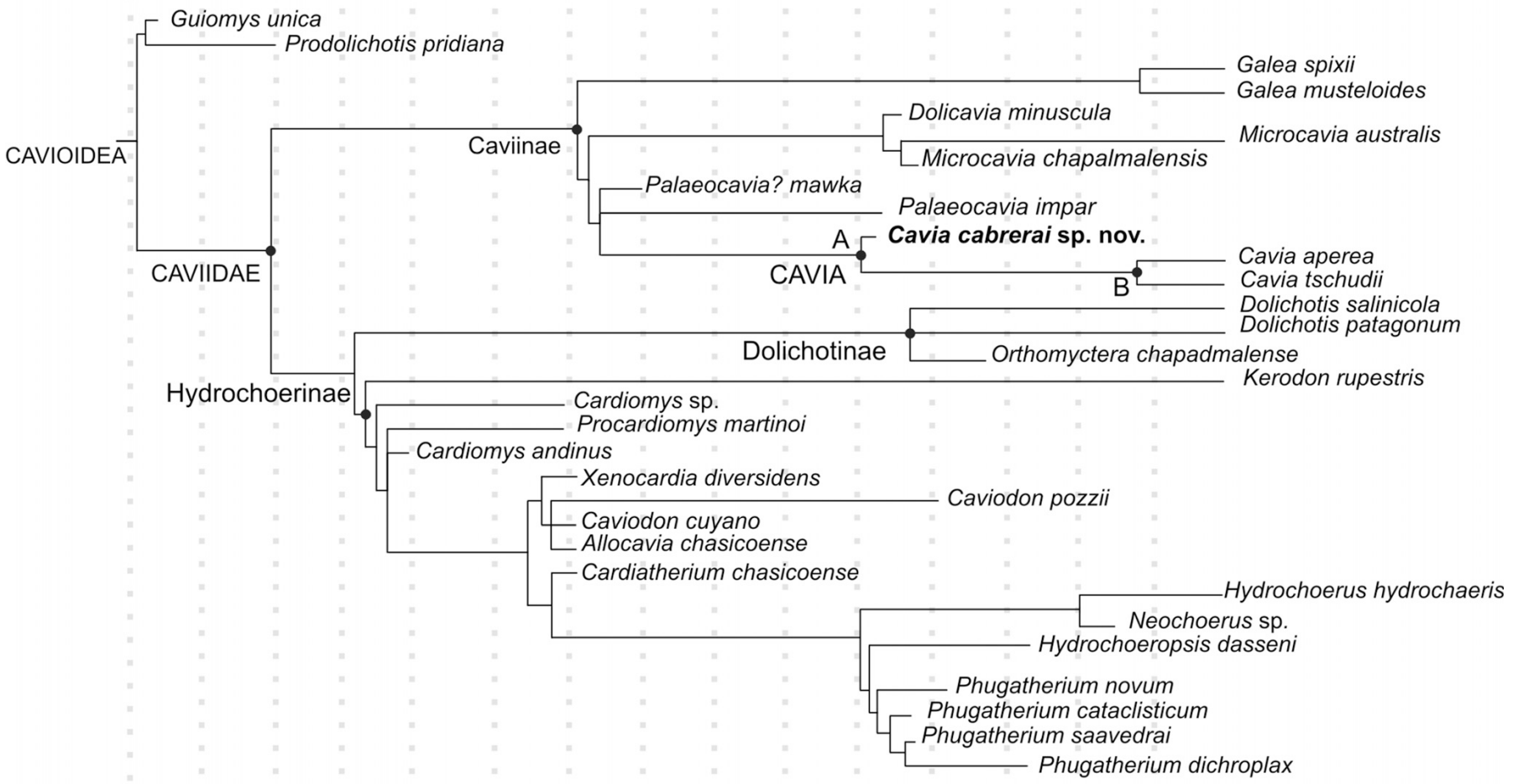

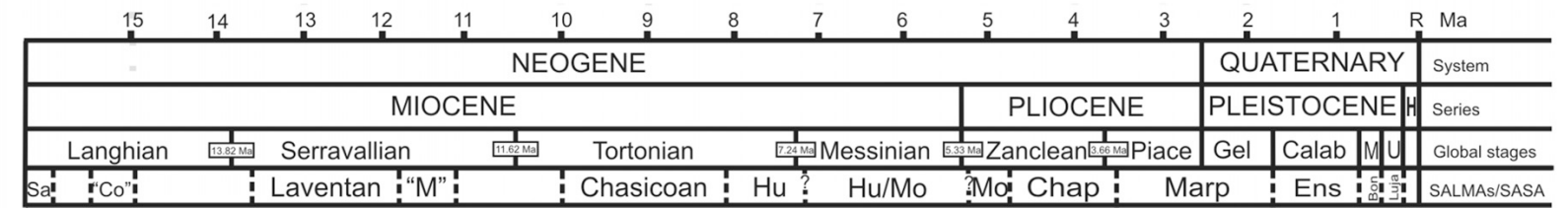

FIGURE 4. Reduced consensus from the second cladistic analysis (ignoring the fossil taxon Microcardiodon huemulensis), showing the node Caviidae. A, node Cavia; $\mathbf{B}$, node of extant Cavia species. The phylogenetic tree was calibrated against the first appearance of taxa in the fossil record (modified from Pérez and Pol, 2012). Abbreviations: Bon, Bonaerian; Calab; Calabrian; Chap, Chapadmalalan; 'Coll', 'Colloncuran'; Ens, Ensenadan; Gel, Gelasian; H, Holocene; Hu, Huayquerian; Luja, Lujanian; 'M', 'Mayoan'; M, Middle; Ma, megaannum; Marp, Marplatan; Mo, Montehermosan; Piace, Piacenzian; Sa, Santacrucian; SALMAs, South American Land Mammal ages; SASA, South American Stage ages. 
above, the cheek teeth of $C$. cabrerai, sp. nov., are less laminar than those of extant species, a condition that the new species shares with $C$. vates.

\section{Body Mass}

Cavia magna is the largest living wild species of Cavia, with an average body mass of $635 \mathrm{~g}$ for adult males, and reaching up to 840 g (Ximénez, 1980:table 1; Table 2). The maximum p4-m3 length (adult males) of C. magna reaches $16.8 \mathrm{~mm}$ (Ximénez, 1980:table 1). Although the posterior margin of the $\mathrm{m} 3$ is not completely preserved in the holotype of $C$. cabrerai, sp. nov., the remaining posterior face of this tooth indicates that $\mathrm{p} 4-\mathrm{m} 3$ length was at least $17.5 \mathrm{~mm}$ (Table 1). In addition, the lower diastema length and mandibular height (taken at diastema level) are greater than those of $C$. magna (Table 1; see also Ximénez, 1980:table 1). In all comparable dimensions, C. cabrerai, sp. nov., is larger than specimens of $C$. aperea, $C$. porcellus, or $C$. magna (see Table 1). In agreement with its relatively large dimensions, the BM estimated for C. cabrerai, sp. nov., is above $1200 \mathrm{~g}$, larger than the extant wild species of Cavia (Table 2). The body masses estimated for two specimens of $C$. porcellus and $C$. aperea (calculated using the equation of Legendre, 1986) were consistent with their known BM (Table 2). These results support the estimated BM for C. cabrerai, sp. nov. On this basis, C. cabrerai, sp. nov., is characterized as larger than all extant wild species of Cavia as well as the extinct $C$. galileoi, C. lamingae, and C. vates (Lock and Montenegro, 1985:table 2; Table 2).

\section{DISCUSSION}

\section{Systematics of Cavia cabrerai, sp. nov., and Significance of Dental Features}

Using the character-based concept to define Cavia, the following traits described for C. cabrerai, sp. nov., support its inclusion in this genus (Kraglievich, 1930; Pascual and Ortega Hinojosa, 1966; Quintana, 1997, 1998; Verzi and Quintana, 2005; MadozzoJaén and Pérez, 2016): (a) second crest of molars (i.e., first crest of second prism) wider than that of the Caviinae Palaeocavia, Dolicavia minuscula, Galea, and Microcavia; (b) tendency toward lamination of the prisms; (c) primary lingual flexid deeper than in other genera of Caviinae; (d) anterolingual widening in the anterior crest of the posterior prism of the teeth ( = AWPP); and (e) hypoflexid deeper and narrower than other genera of Caviinae. Note that some of these characters are recovered as synapomorphies (characters 86 state 3 and 101 state 2 ) at the node that contains new fossil and extant species of Cavia (see below).

The prisms in the new species are more anteroposteriorly compressed, and the flexids are deeper (revealing a clear tendency toward tooth lamination) than any other non-Cavia Caviinae (such as Microcavia, Galea, or D. minuscula). In contrast to Microcavia, Galea, D. minuscula, Palaeocavia, the extinct Cavia galileoi (Verzi and Quintana, 2005), and C. vates (Winge 1887), C. cabrerai, sp. nov., presents a well-differentiated AWPP.

Additionally, at least three features of $C$. cabrerai, sp. nov., present an intermediate condition between the extinct species Palaeocavia impar, P. chapalmalense, and Palaeocavia? mawka and the extant species of Cavia (Fig. 3A-D): (1) degree of tooth lamination: prisms are more compressed anteroposteriorly than those of Palaeocavia but less than those of extant Cavia species (Quintana, 1998; Verzi and Quintana, 2005); (2) a primary lingual flexid (HPI) narrower and shallower than that of extant species of Cavia, and deeper than that of Palaeocavia; and (3) a hypoflexid less penetrating than that of extant species of Cavia, and deeper than that of Palaeocavia (Fig. 3A-D).

The high degree of anteroposterior compression of the prisms, the great depth of the HPI and the hypoflexid, the lingual isthmus formed by a single layer of enamel, and the well-defined wapp seem to be non-independent features related to the acquisition of a laminar occlusal pattern. Cavia cabrerai, sp. nov., shows a lesser degree of tooth lamination than the extant species.

In summary, the analysis of the dental characters supports the inclusion of C. cabrerai, sp. nov., within Cavia and indicates that this species displays a more primitive dental morphology than the extant species of the genus.

\section{Cladistic Analyses}

The results of our phylogenetic analyses include the new species in the genus Cavia (following character-based definition of this genus; see above). In the first analysis, using the same character-state coding as in the original data set (Madozzo-Jaén and Pérez, 2016), the parsimony analysis resulted in 136 most parsimonious trees (MPTs), of 3246 steps (consistency index [CI] = 0.64 ; retention index $[\mathrm{RI}]=0.55$ ). In all MPTs, $C$. cabrerai, $\mathrm{sp}$. nov., is within the clade that contains the extant $C$. tschudii and C. aperea. However, the relationships among Cavia species are not resolved, and in the strict consensus, $C$. cabrerai, sp. nov., collapses in a polytomy with $C$. aperea and $C$. tschudii (Supplementary Data 3). The rest of the topology is identical to that of the strict consensus obtained by Madozzo-Jaén and Pérez (2016:supplementary data 3 ).

Our second phylogenetic analysis resulted in 136 most parsimonious trees (MPTs) of 3248 steps $(\mathrm{CI}=0.643$; $\mathrm{RI}=0.55)$, in which C. cabrerai, sp. nov., was recovered as the sister taxon of the extant species of Cavia. In the reduced consensus (Supplementary Data 4; Fig. 4) obtained from this analysis (ignoring alternative positions taken by the unstable taxon 22, Microcardiodon huemulensis; see Madozzo-Jaén and Pérez, 2016), the position of Cavia species in the context of Caviinae is indicated. In all MPTs the clade formed by C. cabrerai, sp. nov., and extant species of Cavia (node A in Fig. 4) is supported by four unambiguous synapomorphies: shape of the anterior lobe of $\mathrm{m} 1-\mathrm{m} 2$ laminar, being less anteroposteriorly compressed than the anteroposterior diameter of the hypoflexid (character 86 state 3); depth of HPI in $\mathrm{m} 1-\mathrm{m} 2$ up to $50 \%$ of the teeth (character 96 state 2); hypoflexid narrow and very long (character 100 state 2); and relative size of lower molars subequal (character 103 state 3 ). The clade of extant Cavia species (node B in Fig. 4) is supported by two unambiguous synapomorphies: shape of the anterior lobe of $\mathrm{m} 1-\mathrm{m} 2$ strongly laminar, being more anteroposteriorly compressed than the hypoflexid (character 86 state 4); and HPI in $\mathrm{m} 1-\mathrm{m} 2$ reaching the labial end of the teeth (character 96 state 3 ). The remaining topology of the strict consensus is the same as obtained in the first analysis and that of Madozzo-Jaén and Pérez (2016). The character-state changes of the characters 86 and 96 indicate that Cavia cabrerai, sp. nov., has a molar morphology that is plesiomorphic with respect to that of extant species of the genus.

\section{Earliest Occurrence of Cavia: Molecular and Paleontological Data}

Cavia cabrerai, sp. nov., represents the oldest species attributable to this genus. So far, the oldest record of Cavia (C. galileoi) was for the late Pliocene (Verzi and Quintana, 2005). Opazo (2005) estimated $4.1 \pm 1.6 \mathrm{Ma}$ for the divergence of extant Cavia species. A later molecular systematic study of several Cavia species estimated the origin of the genus (crown clade) to have taken place in the late Miocene (Dunnum and Salazar-Bravo, 2010). The latter authors proposed that Cavia magna would have originated earlier than other species of the genus, at $6.2(4.7-7.9) \mathrm{Ma}$, whereas the split between the lineages leading to $C$. aperea and $C$. tschudii was estimated at $4.7(3.4-6.3) \mathrm{Ma}$, close to the MiocenePliocene boundary. The absolute age of an ash bed that overlies C. cabrerai, sp. nov., dated at $4.72 \pm 0.08$ Ma (Bonini et al., in press), and the estimated age of $C$. cabrerai, sp. nov. 
(ca. 4.74 Ma), is consistent with the estimates from molecular data. The oldest occurrence of Cavia in the paleontological record supports that the origin of Cavia took place at least by the earliest Pliocene, near the Miocene-Pliocene boundary.

Future phylogenetic studies that integrate morphological and molecular data, including Cavia cabrerai, sp. nov., and a more extensive taxon sampling among Cavia species, are needed to propose a precise chronology of divergence times of the species of this genus and to understand the early evolutionary radiation of these rodents.

\section{Paleoenvironmental Implications}

Cavia specimens were not recovered at the intensively prospected sediments of the Las Arcas and Chiquimil formations, nor at the lower and middle levels of the Andalhuala Formation, outcropping in northwestern Argentina (Riggs and Patterson, 1939; Marshall and Patterson, 1981; Bossi et al., 1987; Bonini, 2014; Esteban et al., 2014; Bonini et al., 2015). Thus, the appearance of specimens of Cavia cabrerai, sp. nov., at San Fernando Norte suggests that this species is close to the earliest occurrence of this genus in northwestern Argentina.

It recently was recognized that the evolutionary history of Cavia species seems to have been closely linked to the rise of the Andes as well as environmental changes occurring across South America (Dunnum and Salazar-Bravo, 2010). It is possible that the earliest speciation events of Cavia, involving the origin of $C$. cabrerai, sp. nov., were triggered by increasing seasonality and consequent expansion of relatively more arid conditions and open areas close to the Miocene-Pliocene transition (Pascual et al., 1996; Cerling et al., 1997; Zachos et al., 2001; Ortiz-Jaureguizar and Cladera, 2006). Isotopic (Latorre et al., 1997; Kleinert and Strecker, 2001, Bossi and Muruaga, 2009; Hynek et al., 2012), paleobotanic (Anzótegui et al., 2007; Garralla et al., 2016), sedimentological (Bossi et al., 1999; Muruaga, 1999, 2001a, 2001b; Bossi and Muruaga, 2009; Bonini et al., in press), and tectonic (Bossi et al., 2001; Bossi and Muruaga, 2009) studies carried out near the study area support the idea of climatic deterioration as a consequence of the rising of mountain chains east of San Fernando Norte, near the Miocene-Pliocene boundary.

In this context, it is interesting to note that Cavia has laminar and more complex cheek teeth, possessing more interlaminar cement than the living and extinct small- to middle-sized nonCavia caviines and dolichotines (Microcavia, Galea, Palaeocavia, Dolicavia, and Orthomyctera). Dental complexity (sensu Evans et al., 2007) is correlated to diet and ability to process food. Consequently, compared with Microcavia, Dolicavia, and Palaeocavia, the greater complexity of the cheek teeth of Cavia cabrerai, sp. nov., can be interpreted as a way of increasing the mechanical capacity to process relatively demanding foods. Cavia cabrerai, sp. nov., seems to have had specialized teeth that were better adapted to consume more abrasive food items than the other extinct caviines. The hypsodonty and crown complexity, with abundant cement, of Cavia cabrerai, sp. nov., could be related to abrasive particle consumption (e.g., sand, dust, or volcanic glass) adhering to the surface of food or accidentally ingested, as inferred for other extinct and extant hypsodont mammals (Janis, 1988; Damuth and Janis, 2001; Jardine et al., 2012; Candela et al., 2013; Reguero et al., 2015, and references herein). In this framework, the appearance of Cavia in northwestern Argentina could have been triggered by the expansion of relatively open savanna-like environments and increasingly arid conditions developed under climatic seasonality in the Andean region near the Miocene-Pliocene boundary. Note that the first appearance of the genus during the late Pliocene in the most austral latitudes of Buenos Aires Province was also associated with the expansion of arid environments (Verzi and Quintana, 2005). Future investigation is needed to assess if the appearance of Cavia cabrerai, sp. nov., at the Miocene-Pliocene boundary of northwestern Argentina is coincident with other species appearances or disappearances.

\section{ACKNOWLEDGMENTS}

We thank D. Voglino (MPS-Z), D. Verzi and I. Olivares (MLP), and P. Teta (MACN) for permission to study the materials under their care. We especially thank K. L. Hansen, curator of ZMUC, for facilitating several photos of specimens of Cavia vates, D. Voglino and M. Lugo for capable field assistance, and J. M. Capuano for their help in the treatment of databases. We especially thank M. E. Pérez (Museo Paleontológico Egidio Feruglio) for her valuable comments on an earlier version of this work. We want to thank U. Pardiñas, an anonymous reviewer, and editor F. Bibi for the comments and suggestions that greatly improved the manuscript.

\section{LITERATURE CITED}

Ameghino, F. 1888. Lista de las especies de mamíferos fósiles del Mioceno superior de Monte Hermoso, hasta ahora conocidas. E. Coni, Buenos Aires, 21 pp.

Ameghino, F. 1889. Contribución al conocimiento de los mamíferos fósiles de la República Argentina. Actas de la Academia Nacional de Ciencias de Córdoba 6:1-1027.

Ameghino, F. 1908. Las Formaciones sedimentarias de la región litoral de Mar del Plata y Chapadmalal. Anales del Museo Nacional de Buenos Aires 10:342-428.

Anzótegui, L. M., Y. M. Horn, and R. Herbst. 2007. Paleoflora (Fabaceae y Anacardiaceae) de la Formación Andalhuala (Plioceno inferior). provincia de Catamarca, Argentina. Ameghiniana 44:525-535.

Bonini, R. A. 2014. Bioestratigrafía y diversidad de los mamíferos del Neógeno de San Fernando y Puerta de Corral Quemado (Catamarca, Argentina). Ph.D. dissertation, Universidad Nacional de La Plata, Facultad de Ciencias Naturales y Museo de La Plata, La Plata, Argentina, 366 pp.

Bonini, R. A., and D. Brandoni. 2015. Pyramiodontherium Rovereto (Xenarthra, Tardigrada, Megatheriinae) from the Early Pliocene of San Fernando, Catamarca Province, Argentina. Ameghiniana 52:647-655.

Bonini, R. A., and S. M. Georgieff. 2013. Reconsideración estratigráfica del Neógeno del área norte de la localidad de San Fernando, departamento de Belén (Catamarca). II Simposio del Mioceno-Pleistoceno del Centro y Norte de Argentina. Ameghiniana 50(6):R5.

Bonini, R. A., A. M. Candela, S. M. Georgieff, and M. A. Reguero. 2015. Bioestratigrafía, Geocronología y Diversidad de los Mamíferos del Neógeno de San Fernando, Departamento Belén, Catamarca; p. 5 in Libro de Resúmenes del III Simposio del Mioceno-Pleistoceno del Centro y Norte de Argentina, Corrientes, 17-19 de Septiembre de 2015.

Bonini, R. A., S. M. Georgieff, and A. M. Candela. In press. Stratigraphy, geochronology, and paleoenvironments of Miocene-Pliocene boundary of San Fernando, Belén (Catamarca), northwest of Argentina. Journal of South American Earth Sciences.

Bonvicino, C. R., J. A. de Oliveira, and P. S. D’Andrea. 2008. Guia dos Roedores do Brasil, com chaves para gêneros baseadas em caracteres externos. Centro Pan-Americano de Febre Aftosa-OPAS/ OMS, Série de Manuais Técnicos 11. Rio de Janeiro, Brazil, 120 pp.

Bossi, G. E., and C. Muruaga. 2009. Estratigrafía e inversión tectónica del rift neógeno en el Campo del Arenal, Catamarca, NO Argentina. Andean Geology 36:311-340.

Bossi, G. E., C. Muruaga, and S. M. Georgieff. 1999. El Neógeno del faldeo occidental del cerro Pampa, Catamarca; pp. 483-486 in G. González Bonorino, R. Omarini, and J. Viramonte (eds.), Geología del Noroeste Argentino: Relatorio del XIV Congreso Geológico Argentino, Salta. Asociación Geológica Argentina.

Bossi, G. E., R. Ovejero, and M. Strecker. 1987. Correlación entre los perfiles del Terciario superior en la Puerta de Corral QuemadoHualfín y de Entre Ríos (Chiquimil). Provincia de Catamarca, Argentina; pp. 117-120 in Actas del X Congreso Geológico Argentino, San Miguel de Tucumán, Facultad de Ciencias Naturales 
e Instituto Miguel Lillo, Universidad Nacional de Tucumán. Asociación Geológica Argentina. Volume 2.

Bossi, G. E., S. Georgieff, I. Gavriloff, L. Ibáñez, and C. Muruaga. 2001 Cenozoic evolution of the intramontane Santa María Basin, Pampean Ranges, northwestern Argentina. Journal of South American. Earth Sciences 14:725-734.

Bowdich, T. E. 1821. An analysis of the natural classifications of mammalia for the use of students and travelers. J. Smith, Paris, 115 pp.

Bridge, J. S., and R. V. Demico. 2008. Earth Surface Processes, Landforms and Sediment Deposits. Cambridge University Press, New York, $815 \mathrm{pp}$.

Bridge, J. S., G. A. Jalfin, and S. M. Georgieff. 2000. Geometry, lithofacies and spatial distribution of Cretaceous fluvial sandstoneodies, San Jorge Basin, Argentina: outcrop analog for the hydrocarbon-hearing Chubut Group. Journal of Sedimentary Research 70:341-359.

Brito, J., and J. Fernández de Córdova. 2016. Nuevas localidades y ampliación de la distribución del cuy silvestre de Patzelt Cavia patzelti (Rodentia: Caviidae) en Ecuador. Mastozoología Neotropical 23:157-163.

Cabrera, A. 1953. Los roedores argentinos de la familia Caviidae. Facultad de Agronomía y Veterinaria, Universidad de Buenos Aires, Escuela de Veterinaria Publicación 6:1-93.

Candela, A. M., G. Cassini, and N. Nasif. 2013. Fractal dimension and cheek teeth crown complexity in the giant rodent Eumegamys paranensis. Lethaia 46:369-377.

Cerling, T. E., J. M. Harris, B. J. MacFadden, M. G. Leakey, J. Quade, V. Eisenmann, and J. R. Ehleringer. 1997. Global vegetation change through the Miocene/Pliocene boundary. Nature 389:153-158.

Cherem, J. J., and J. Ferigolo. 2012. Descrição do sincrânio de Cavia aperea (Rodentia, Caviidae) e comparação com as demais espécies do gênero no Brasil. Papéis Avulsos de Zoologia 52:21-50.

Cherem, J. J., J. Olimpio, and A. Ximenez. 1999. Descrição de uma nova espécie do gênero Cavia Pallas, 1766 (Mammalia-Caviidae) das Ilhas dos Moleques do Sul, Santa Catarina, Sul do Brasil. Biotemas 12:95-117.

Damuth, J., and C. M. Janis. 2011. On the relationship between hypsodonty and feeding ecology in ungulate mammals, and its utility in palaeoecology. Biological Reviews 86:733-758.

Dunnum, J. L. 2015. Family Caviidae; pp. 690-726 in J. L Patton, U. F. J. Pardiñas and G. D. 'Elía (eds.), Mammals of South America: Volume 2 Rodents. The University of Chicago Press, Chicago, IL.

Dunnum, J. L., and J. Salazar-Bravo. 2010. Phylogeny, evolution, and systematics of the Galea musteloides complex (Rodentia: Caviidae) Journal of Mammalogy 91:243-259.

Eisenberg, J. F. 1989. Mammals of the Neotropics, The Northern Neotropics, Volume 1. University of Chicago Press, Chicago, Illinois, $449 \mathrm{pp}$.

Eisenberg, J. F., and K. H. Redford. 1999. Mammals of the Neotropics: The Central Neotropics. Volume 3: Ecuador, Peru, Bolivia, Brazil. University of Chicago Press, Chicago, Illinois, 609pp.

Esteban, G., N. Nasif, and S. M. Georgieff. 2014. Cronobioestratigrafía del Mioceno tardío-Plioceno temprano, Puerta de Corral Quemado y Villavil, provincia de Catamarca, Argentina. Acta Geológica Lilloana 26:165-192.

Evans, A. R., G. P. Wilson, M. Fortelius, and J. Jernvall. 2007. High level similarity of dentitions in carnivorans and rodents. Nature 445:78-81.

Fischer von Waldheim, G. 1817. Adversaria zoologica. Mémoires de la Société Impériale des Naturalistes de Moscou 5:357-446.

Garralla, S. S., L. M. Anzótegui, and L. R. Mautino. 2016. Relaciones paleofloristicas del Mioceno-Plioceno del norte argentino. Publicación Electrónica de la Asociación Paleontológica Argentina 16:1-13.

Goloboff, P., J. Farris, and K. Nixon. 2008. TNT, a free program for phylogenetic analysis. Cladistics 24:774-786.

Hadler, P., D. H. Verzi, M. G Vucetich, J. Ferigolo, and A. M. Ribeiro. 2008. Caviomorphs (Mammalia, Rodentia) from the Holocene of Rio Grande do Sul State, Brazil: systematics and paleoenvironmental context. Revista Brasileira de Paleontologia 11:97-116.

Hynek, S. A., B. H. Passey, J. L. Prado, F. H Brown, T. E. Cerling, and J. Quade. 2012. Small mammal carbon isotope ecology across the Miocene-Pliocene boundary, northwestern Argentina. Earth and Planetary Science Letters 321-322:177-188.

Janis, C. M. 1988. Estimation of tooth volume and hypsodonty indices in ungulate mammals, and the correlation of these factors with dietary preference. Mémoires du Muséum national d'Histoire naturelle, série C 53:367-387.

Jardine, P. E., C. M. Janis, S. Sahney, and M. J. Benton. 2012. Grit not grass: concordant patterns of early origin of hypsodonty in Great Plains ungulates and Glires. Palaeogeography, Palaeoclimatology, Palaeoecology 365:1-10.

Kleinert, K., and M. R. Strecker. 2001. Climate change in response to orographic barrier uplift: paleosol and stable isotope evidence from the late Neogene Santa María basin, northwestern Argentina. Geological Society of America Bulletin 113:728-742.

Kraglievich, L. 1930. Un nuevo e interesante roedor de la fauna terciaria de Entre Ríos Caviodon (Lelongia) paranesis n. subgen. n. sp. Anales de la Sociedad Científica Argentina 110:178-184.

Kraglievich, L. 1940. Descripción detallada de diversos roedores argentinos terciarios clasificados por el autor; pp. 297-330 in A. J. Torcelli (ed.), Obras de Geología y Paleontología. La Cultura argentina, Buenos Aires, Vol. 2

Latorre, C., J. Quade, and W. C. Mcintosh. 1997. The expansion of the C4 gases and global changes in the Late Miocene: stable isotope evidence from the Americas. Earth and Planetary Science Letters 146:83-96.

Legendre, S. 1986. Analysis of mammalian communities from the Late Eocene and Oligocene of southern France. Palaeovertebrata $16: 191-212$

Linnaeus, C. 1758. Systema naturae per regnum tria naturae, secundum classes, ordines, genera, species, cum characteribus, differentiis, synonymis, locis. Editio decima, reformata. Holmiae: Laurentii Salvii, $1: 1-824$.

Locks, M., and E. Montenegro. 1985. Contribuicao a paleontologia do 'Grande abrigo da Lapa Vermelha Emperaire', Pedro Leopoldo, MG, Brasil. $\mathrm{N}^{\circ} 1$ - um novo caviineo Quaternario (MammaliaRodentia) 81-86 in: D.A. Campos, C.S. Ferreira, I.M. Brito, C.F. Viana (eds). Coletanea de Trabalhos Paleontologicos. Rio de Janeiro: DNPM. Brasilia: Departamento Nacional da Producao Mineral, Serie Geologia. 27 p. 81-86.

Madozzo-Jaén, J. M. C., and M. E. Pérez. 2016. The most ancient caviine rodent (Hystricognathi, Cavioidea) comes from the late Miocene of northwest Argentina (South America). Historical Biology 17:376383. doi: $10.1080 / 08912963.2016 .1166360$.

Marshall, L. G., and B. Patterson. 1981. Geology and geochronology of the mammal-bearing Tertiary of the Valle de Santa María and Río Corral Quemado, Catamarca Province, Argentina. Fieldiana, Geology (New Series) 9:1-80.

Muruaga, C. M. 1999. Estratigrafía de sedimentos terciarios aflorantes en la Sierra de Hualfín, NE de Catamarca; pp. 479-482 in G. González Bonorino, R. Omarini, and J. Viramonte (eds.), Geología del Noroeste Argentino: Relatorio del XIV Congreso Geológico Argentino, Salta. Asociación Geológica Argentina.

Muruaga, C. M. 2001a. Estratigrafía y desarrollo tectosedimentario de sedimentos terciarios en los alrededores de la Sierra de Hualfín, borde suroriental de la Puna, Catamarca, Argentina. Revista de la Asociación Argentina de Sedimentología 8:27-50.

Muruaga, C. M. 2001b. Petrografía y procedencia de areniscas terciarias en la Subcuenca de Hualfín, provincia de Catamarca, noroeste de Argentina. Revista de la Asociación Argentina de Sedimentología 8:15-35.

Opazo, J. C. 2005. A molecular timescale for caviomorph rodents (Mammalia, Hystricognathi). Molecular Phylogenetics and Evolution 37:932-937.

Ortiz, P. E., and J. P. Jayat. 2012. Range extension of Cavia tschudii Fitzinger, 1867 (Mammalia: Caviidae) and first record in Catamarca, northwestern Argentina. Check List 8:782-783.

Ortiz-Jaureguizar, E., and G. A. Cladera. 2006. Paleoenvironmental evolution of southern South America during the Cenozoic. Journal of Arid Environments 66:498-532.

Pallas, P. S. 1766. Miscellanea Zoologica quibus novae imprimis atque obscurae animalium species describuntur et observationibus iconibusque illustrantur. Peter van Cleef, The Hague, $224 \mathrm{pp}$.

Pascual, R., E. Ortiz Jaureguizar, and J. Prado. 1996. Land mammals: paradigm for Cenozoic South American geobiotic evolution; pp 1319 in G. Arratia (ed.), Contributions of Southern South America to Vertebrate Paleontology. Münchner Geowissenschaftliche Abhandlungen (A) 39 (Contribution of Southern South America to Vertebrate Paleontology). 
Pascual, R., and E. J. Ortega Hinojosa. 1966. Caviinae; pp. 108-112 in A. V. Borrello (ed.), Paleontografia Bonaerense. Vol. IV: Vertebrados. Comisión de Investigaciones Científicas, Provincia de Buenos Aires, La Plata.

Pérez, M. E., and D. Pol. 2012. Major radiations in the evolution of Caviid rodents: reconciling fossils, ghost lineages, and relaxed molecular clocks. PloS ONE 7:10:e48380. doi:10.1371/journal.pone.0048380.

Quintana, C. A. 1996. Diversidad del roedor Microcavia (Caviomorpha, Caviidae) de América del Sur. Mastozoología Neotropical 3:63-86.

Quintana, C. A. 1997. El roedor Dolicavia minuscula (Caviomorpha, Caviidae) del Plioceno superior de la provincia de Buenos Aires, Argentina. Historia Animalium 3:55-71.

Quintana, C. A. 1998. Relaciones filogenéticas de roedores Caviinae (Caviomorpha: Caviidae), de América del Sur. Boletín de la Real Sociedad Española de Historia Natural (Sección Biológica) 94:125-134.

Redford, K. H., and J. F. Eisenberg. 1992. Mammals of the Neotropics: The Southern Cone. Volume 2: Chile, Argentina, Uruguay, Paraguay. University of Chicago Press, Chicago, Illinois, $430 \mathrm{pp}$.

Reguero, M. A., A. M. Candela, C. I. Galli, R. Bonini, and D. Voglino. 2015. A new hypsodont notoungulate (Hegetotheriidae, Pachyrukhinae) from the Late Miocene of the Eastern Cordillera, Salta Province, northwest of Argentina. Andean Geology 42:56-70.

Riggs, E. S., and B. Patterson. 1939. Stratigraphy of Late Miocene and Pliocene deposits of the Province of Catamarca (Argentina) with notes on the faunae. Physis 14:143-162.

Spotorno, A. E., J. P. Valladares, J. C. Martín, and H. Zeballos. 2004. Molecular diversity among domestic guinea-pigs (Cavia porcellus) and their close phylogenetic relationship with the Andean wild species Cavia tschudii. Revista Chilena de Historia Natural 77:243-250.
Ubilla, M., and M. T. Alberdi. 1990. Hippidion sp. (Mammalia, Perissodactyla, Equidae) en sedimentos del pleistoceno superior del Uruguay (Edad Mamífero Luganense). Estudios Geológicos 46:453464.

Verzi, D. H., and C. Quintana. 2005. The caviomorph rodents from the San Andrés Formation, east- central Argentina, and global Late Pliocene climatic change. Palaeogeography, Palaeoclimatology, Palaeoecology 219:303-320.

Winge, H. 1887. [1888]. Jordfunde og nulevende Gnavere (Rodentia) fra Lagoa Santa, Minas Geraes, Brasilien: med udsigt over gnavernes indbyrdes slaegtskab. E Museo Lundii, Kjöbenhavn 1(3):1-178 + 8 pls.

Wood, A. E. 1955. A revised classification of the rodents. Journal of Mammalogy 36:165-187.

Woods, C. A., and W. Kilpatrick. 2005. Infraorder Hystricognathi; pp. $1538-1600$ in D. E. Wilson and D. M. Reeder (eds.), Mammal Species of the World, A Taxonomic and Geographic Reference. The Johns Hopkins University Press, Baltimore, Maryland.

Ximénez, A. 1980. Notas sobre el género Cavia Pallas con la descripción de Cavia magna sp. n. (Mammalia-Caviidae). Revista Nordestina de Biologia 3:145-179.

Zachos, J., M. Pagani, L. Sloan, E. Thomas, and K. Billups. 2001. Trends, rhythms, and aberrations in global climate $65 \mathrm{Ma}$ to Present. Science 292:686-693.

Submitted October 25, 2016; revisions received June 9, 2017; accepted June 13, 2017.

Handling editor: Faysal Bibi. 